\title{
Impact of the Economic Recession on Toll Highway Concessions in Spain
}

\author{
José Manuel Vassallo ${ }^{1}$; Alejandro Ortega ${ }^{2}$; and María de los Ángeles Baeza ${ }^{3}$
}

\begin{abstract}
After joining the European Union in 1986, Spain experienced steady economic growth that enabled the country to grow at a greater pace than other European countries. During this period, the government of Spain opted for major investments in public infrastructure by taking advantage both of the funding provided by the European Union and of several types of public-private-partnership (PPP) approaches. Within this framework, the government of Spain between 1996 and 2004 procured a series of toll highway concessions. These concessions entered into operation a few years before the global economic recession made itself felt in Spain. The concession contracts signed between the government and some private consortia allocated most of the risks (expropriation, construction, and traffic) to the private sector. In this paper the impact that the economic recession has had on the business performance of the concessionaires is assessed, and the effectiveness of the measures adopted by the government to help the concessionaire to avoid bankruptcy is analyzed. It was found that some of the guarantees offered by the legal framework to the concessionaires in case of bankruptcy are prompting an outcome that could negatively affect the users. In addition to that, some suggestions as to how to better allocate risk in toll highway concessions in the future are provided.
\end{abstract}

CE Database subject headings: Toll roads; Traffic management; Spain; Partnerships; Economic factors.

Author keywords: Economic recession; Toll road; Traffic estimates; Concession contract; Spain; Public-privatepartnership.

\section{Introduction}

Before the economic recession arrived in Europe, Spain was considered one of the most important and promising economies of the European Union (EU). Since the adoption of the single currency in 1999 and until 2007, Spain kept up a relentless economic development, which resulted in steady annual average growth in gross domestic product (GDP) that was consistently above the average for the European Union. During this period, public infrastructure investment reached the highest levels in the history of Spain. In fact, the public investment to GDP ratio in Spain became one of the highest among the EU countries (INE 2009).

During this period, the government decided to push the investment in infrastructure for two reasons. First, the stock of public capital in Spain was lower than the average for the European Union and in order to compete with other European countries, Spain needed to quickly improve its infrastructure network. Second, the peripheral location of Spain at the edge of the continent made it even more necessary to expand the infrastructure networks so as to be sufficiently competitive.
One of the key mechanisms that helped push infrastructure investment in Spain was the implementation of different publicprivate-partnership (PPP) approaches. Among them, the use of concession contracts to procure toll highways, which have a long tradition in the Spanish legal framework to encourage private companies to participate in the design, construction, maintenance, and operation of toll highways, was extensively used. This approach was based on transferring most of the risks (expropriation, construction, and traffic) to the private sector [Organisation for Economic Co-operation and Development (OECD) 2007].

The arrival of the world economic recession in Europe in 2008 had devastating effects for some countries of the EU, and Spain was among them. Greece and Ireland have had to undergo intervention by the European Union. The large indebtedness of these countries along with their low levels of productivity caused the financial markets to start regarding them with apprehension. In March 2011, the spread on the Portuguese bond was $4.76 \%$ more than on German bonds of comparable duration, which gives substance to the possibility of the EU feeling it may have to intervene in Portugal as well. In fact, the financial markets appear by their behavior to have assumed such future intervention. Spain came under scrutiny for a possible intervention before, in the Fall of 2010. However, since then, the threat of an EU intervention has substantially diminished because of the stringent measures adopted by the govemment of Spain to reduce its public deficit.

The economic recession has had a large effect on the economics of toll highway concessions, which had transferred most of their risks to the private sector. The objective of this paper is, first, to assess the consequences of the economic recession that struck Spain from 2008 for the outcome of the concession contracts and, second, to analyze the consequences of the measures adopted by the government to mitigate the effects of the recession. The paper concludes with a set of recommendations about a better design of risk allocation in toll highway concession contracts. 


\section{Evolution of Economy in Spain}

Spain is one the most important countries of the EU. At the time this paper was written, Spain was the fifth EU country in terms of both GDP and population after Germany, France, the United Kingdom, and Italy. Spain joined the European Union in 1986, 9 years after the arrival of its democracy.

\section{Consequences of Joining the European Union}

When Spain joined the European Union, it lagged far behind the average of the European countries in terms of the most relevant macroeconomic indicators: income per capita, public capital stock, inflation, interest rates, and unemployment rates (European Monetary Institute 1996). However, the adherence of Spain to the European Union substantially contributed to the improvement of Spain's economy. This effect was particularly outstanding after Spain began using the single currency in 1999.

Fig. 1 shows the evolution over time of some key macroeconomic indicators comparing Spain with the EU-15. The EU-15 includes the first 15 countries to join the European Union and includes all those that are the most economically developed: Germany, France, Belgium, the Netherlands, Luxembourg, Italy, United Kingdom, Austria, Sweden, Denmark, Finland, Ireland, Greece, Spain, and Portugal. Spain for many years experienced a sustained GDP growth above the average of the EU-15. The employment rate defined as the ratio of the working population to the number of people aged between 16 and 65 years old grew at a much faster pace in Spain than in the EU-15. The inflation rate, however, was higher in Spain than in the EU-15, which was likely caused by the increase in economic activity. Finally, the public investment to GDP ratio was much greater in Spain than in the EU-15 because of the effort made by Spain to expand its public infrastructure networks. Despite the good performance of Spain until 2007, things became much worse after 2008. Fig. 1 shows how the recession struck Spain much more sharply than the EU-15 in terms of reduction of GDP growth and the decrease in the employment rate.

\section{Infrastructure Investment}

Several reasons explain why Spain made such a great effort in increasing its public infrastructure from 2000 to 2008. First, Spain's economy boomed during this period so budgetary resources available for infrastructure became more abundant. Second, the European Union provided a lot of funding to Spain to be invested in infrastructure. Third, Spain made good use of different types of PPP approaches in order to raise funds from the private sector to fund infrastructure.

One of the policy goals of the European Union is to promote economic convergence among the European regions. To that end, the EU has put into effect several means of channeling resources so as to cofund infrastructure in the poorest regions of Europe in order to help those regions rise economically so as to approach the average of the European Union (Vassallo 2011). The two most important instruments implemented by the EU for this purpose were the European regional development fund (ERDF) and the cohesion fund $(\mathrm{CF})$. The ERDF provides funding in order to foster productivity in the regions of the European Union with structural problems, especially those whose income per capita is below $75 \%$ of the average of the EU. While the ERDF has been used to fund a variety of initiatives, such as schools, hospitals, programs for rural development, and similar measures, it has also been intensively used for funding infrastructure in the poorest regions.

The CF was created by the European Union in 1994. The role of this fund is to help the poorest EU countries to improve their macroeconomic indicators. The CF was mostly designed to help the poorest countries of the EU to keep on building infrastructure even as they were making efforts to reduce their public deficit.
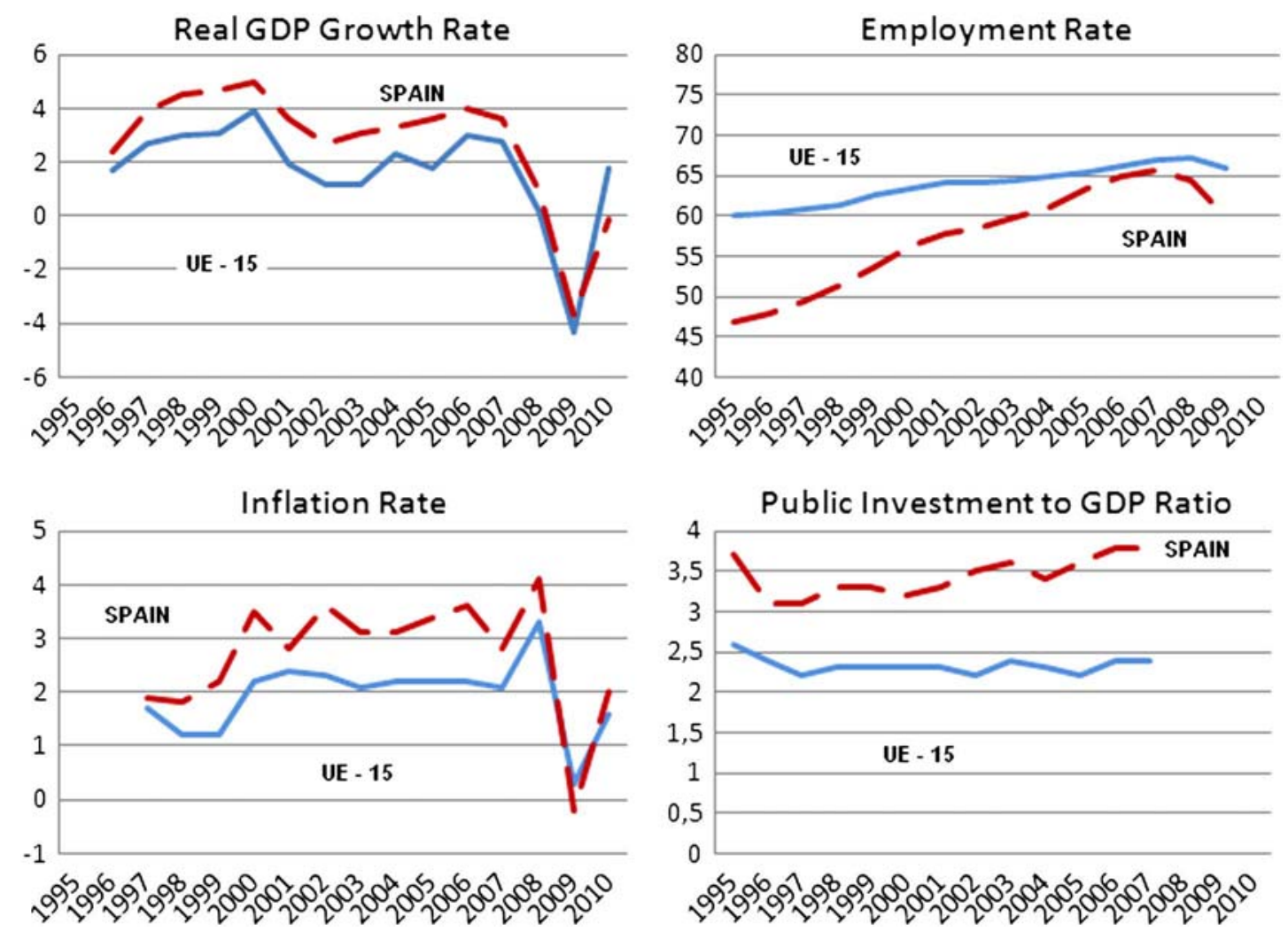

Fig. 1. Evolution of the macroeconomic indicators in Spain and the EU-15 before and after the economic recession 
The CF is allowed to fund transportation and environmental infrastructure only. The EU allows the CF to cofund up to $85 \%$ of the whole capital cost of eligible infrastructure projects. Up to 2006, the only countries eligible to receive cohesion funds in Europe were Spain, Portugal, Greece, and Ireland. Because of its size, Spain received the lion's share of the $\mathrm{CF}$ until 2006. Most of the $\mathrm{CF}$ received by Spain was devoted to the construction of some of the high-speed rail lines.

Spain took full advantage of the funds provided by the EU. From 2000 to 2006, Spain received 16,375 million Euro from the EU for transport infrastructure investment (2,340 million Euro a year on average). However, since 2006, the European funds received by Spain have been steadily dwindling. Two reasons explain this trend: first, Spain has experienced a greater growth than the average of the European Union so it has improved its economic position compared to other countries; second, the countries of Eastern Europe that have recently joined the EU have contributed to reducing the average GDP of the European Union so Spain became relatively less poor after the incorporation of so many new member states with much lower levels of economic development. Consequently, the amount allocated to Spain for transport infrastructure in the period 2007-2013 was reduced to 4,901 million Euro (700 million Euro a year on average). In addition to the European funding, one of the main explanations for the high rate of public investment in Spain was the deliberate promotion of different types of PPPs for the building of infrastructure. From 2003 to 2010, both the central and the regional governments procured infrastructure PPP contracts totaling on average 6,280 million Euro a year, which is approximately $20 \%$ of the public infrastructure investment in Spain.

\section{Economic Recession and Its Causes}

The economic recession in Spain has been caused by both exogenous and endogenous factors. The most important exogenous causes are two: the price rise of raw materials, such as copper and oil, and the influence of the global financial crisis. The endogenous causes are also two: first, the real estate bubble that damaged the financial system due to the great exposure of the Spanish banks to mortgages; second, the limited capacity of Spain to respond to the crisis because of the low productivity of the Spanish workforce, the lack of flexibility in the labor market, and a high indebtedness in both the public and the private sector.

The impact of the economic crisis in Spain has been one of the greatest among the European countries. The country was in recession for seven quarters, which was reflected in negative GDP growths in both 2009 and 2010. This provoked an accelerated increase of the unemployment rate that in 2010 surpassed $20 \%$ of the working population, the highest among the EU-15 countries. In this same year Germany and France, by contrast, had unemployment rates of 7 and $9.7 \%$ respectively.

A report prepared by the Banco de España (2011) claimed that the recovery of Spain will be slow and strongly dependant on the evolution of the European economy. Estimates for 2011 forecast a GDP growth of around $1 \%$ accompanied by an inflation rate of over $2.5 \%$. These forecasts seem to indicate that the crisis will take much longer to be concluded than expected.

The poor economic situation of Spain at that time was also threatened by the likely rise of oil prices caused by the turmoil that in 2011 was taking place in North Africa. This situation can end up having a great impact on Spain's economy because of its high energy dependence on sources abroad. Moreover, in March 2011, the EU announced a rise in the interest rates of the euro to mitigate the inflationary effect that might come from the increase in oil prices, which can end up harming the Spanish economy even more.

\section{Toll Highway Concessions in Spain}

Spain has extensive experience in managing and financing highways through PPPs. Most of the PPPs have been put into effect through concession contracts that have a long tradition in Spanish law. From the beginning, highway concessions in Spain were competitively awarded to private consortia through competitive tenders. This is substantially different from the situation in such other European countries as France and Italy, which directly entrusted toll highways to public-private companies that were mostly controlled by the government. Most of the highway concessions awarded in Spain have been toll highways. In the last few years, however, there has been a great increase in the number of other PPP approaches, such as shadow-toll or performance-based contracts.

\section{History}

Three different periods regarding the implementation of highway concessions in Spain can be identified: from 1967 to 1975, from 1976 to 1995, and from 1996 to the present. Between 1967 and $1975,2,042 \mathrm{~km}$ of toll highways were granted by the central government of Spain. There are two reasons for the Spanish government's decision to start a toll highway program as a means of expanding and improving the Spanish highway network. First, the economic growth that Spain experienced during those years prompted a great rise in traffic, which suddenly made better highways come to be regarded as a necessity. Second, the state budget in Spain was not able to afford such a huge investment, so private funding was the only means available to reach that goal.

The government decided to add certain fiscal advantages and financial guarantees to the highway concession contracts in order to attract funding for such projects from financial institutions and other investors. The main ones were tax breaks, loan guarantees, and exchange insurance provided by the State for those loans denominated in foreign currency. The two petroleum crises that the industrialized countries experienced in the 1970s had a huge impact on the guarantees provided by the Spanish government to highway concessionaires. On the one hand, the rise in gas prices caused traffic growth to be lower than expected. On the other hand, exchange rates became substantially unstable. These factors triggered the guarantees that had been incorporated in the already-existing contracts, which ultimately became very expensive for the government. In fact, the Spanish government continues until today to meet certain financial commitments made to those holding highway concession contracts dating back to the early 1970s.

The results of the implementation of concession contracts in Spain during this period were controversial. On the one hand, highway concessions achieved the goal of providing the country with a modern highway network at a time when the public budget of Spain was not sufficient to afford such a huge cost. On the other hand, the guarantees made by the government to facilitate the funding of those concessions over time became very costly for the country (Izquierdo and Vassallo 2004).

The second stage dates from 1975 to 1995 . In this period, no highway concession was awarded. There were several reasons for this. First, the two petroleum crises in the 1970s destabilized the Spanish economy. Second, after the dictatorship ended, the political atmosphere in Spain was uncertain. Third, and most important, the socialist government, which took office in 1982 and remained in power until 1996, was politically opposed to promoting private concessions as a means to finance highways. Instead, 
the socialist government opted for modernizing the Spanish road network by widening and upgrading the most important roads, turning them into dual-roadway fast lanes with quality standards set well below those for toll highways. This new program was completely funded by the public sector, which funding constituted a significant burden for the Spanish government.

The third stage began in 1996 and continues to the present. In 1996, the conservative People's Party took office in Spain. The need to contain Spain's public deficit was the most difficult challenge facing the new government. This was the main reason why the new government decided to implement once again the policy of offering concessions so as to encourage the participation of the private sector in the financing of new transportation infrastructure. The socialist government, which took office in 2004, retained its faith in the concession system though it promoted fewer toll highways than the People's Party. From 1996 to now, 835 km of new toll highways concessions have been awarded by the central government of Spain through this approach. Table 1 displays a summary of the toll highway concessions awarded by the central government of Spain from 1996 up to now that were in operation at the time this paper was written. The Málaga-Alto de la Pedrizas highway, which at the time of this writing was still under construction, is not included in Table 1.

In order to facilitate the analysis, the toll highway concessions awarded from 1995 on are classified into three different groups. Group 1 is made up of toll concessions competing with conventional single roads in interurban corridors with a low density of population. These are basically toll highways linking an origin with a destination but with low levels of short-distance traffic. The second group is made up of toll motorways that directly compete with free highways experiencing peak-hour or seasonal congestion. They are located around urban areas and are subject to highly changeable urban and transport supply environments. The third group is made up of toll highway concessions in corridors with a high population density; most of them are in tourist destinations along the coast. The toll highways within Group 3 compete not only with single roads but also with free highways in different corridors that may be an alternative for certain origin-destination pairs. Unlike Group 1, toll highways in Group 3 channel traffic to and from a variety of origins and destinations.

\section{Legal Framework}

The legal framework on PPPs in Spain has changed significantly through the years. The first highway concessions were awarded on the basis of specific decrees passed by the government. In 1972 a new law, called the Toll Highway Law, was passed. Its purpose was the regulation of toll highway concession contracts and the public guarantees applicable to them.

However, the most important development regarding legislation about concession contracts in Spain occurred with the approval of the public works concession law in 2003. This law was promptly incorporated as part of the framework of the public contracts law. The objectives of this law were, among others, to update the old highway concession model and to extend it to every type of public works, to reinforce the contribution of private financing for the construction and maintenance of public facilities, and to define a new risk-sharing approach. This law considerably restricted public guarantees, even though it incorporated several mechanisms whereby the public sector could eventually contribute to the financial feasibility of concession contracts.

In 2007, a new public contracts law was passed in Spain in order to transpose new EU legislation about public contracts to the Spanish legal framework. This new law basically maintained the legal framework set up in 2003 regarding concession contracts though some slight modifications were incorporated. Moreover, the new public contracts law made necessary, in its final version, the passage of a new law for the regulation of funding sources for concessions and PPPs in Spain. In 2010, the government circulated a first draft of this law.

One of the most controversial clauses of the Spanish concession law is the one that sets up the compensation to the concessionaire in case of early termination of the contract. This clause establishes that if the contract terminates earlier, and bankruptcy is one of the causes of termination of the contract, the government will have to pay a compensation to the concessionaire for the works that have been built and have not yet depreciated. This compensation will be equal to the capital cost declared by the concessionaire in its financial plan minus the depreciation of the assets calculated according to the accounting norms of Spain. Regardless of the principle under which this guarantee is based, the fact is that this guarantee may have serious negative consequences for the government since the committed payments will immediately increase the size of the

Table 1. Characteristics of Toll Highways Concessions Awarded from 1996

\begin{tabular}{|c|c|c|c|c|c|c|c|c|}
\hline \multirow[b]{2}{*}{ Group } & \multirow{2}{*}{$\begin{array}{l}\text { Toll highway } \\
\text { concession }\end{array}$} & \multirow{2}{*}{$\begin{array}{l}\text { Year of } \\
\text { award }\end{array}$} & \multirow{2}{*}{$\begin{array}{l}\text { Length } \\
(\mathrm{km})\end{array}$} & \multirow[b]{2}{*}{ Type of road } & \multirow{2}{*}{$\begin{array}{l}\text { Competition in } \\
\text { main corridor }\end{array}$} & \multirow{2}{*}{$\begin{array}{c}\text { Other } \\
\text { competition }\end{array}$} & \multicolumn{2}{|c|}{$\begin{array}{l}\text { Tolls for cars Euros/ } \\
\text { vehicles } \times \text { km } 2009\end{array}$} \\
\hline & & & & & & & Minimum & Maximum \\
\hline \multirow[t]{5}{*}{ Group 1} & Ávila-Villacastín & 1999 & 23.1 & Interurban & Single road & & 0.0281 & 0.0763 \\
\hline & $\begin{array}{l}\text { Santiago-Alto de Santo } \\
\text { Domingo }\end{array}$ & 1999 & 56.5 & Interurban & Single road & & 0.0780 & 0.0780 \\
\hline & Segovia-El Espinar & 1999 & 27.7 & Interurban & Single road & & 0.0426 & 0.1059 \\
\hline & León-Astorga & 2000 & 37.7 & Interurban & Single road & & 0.0403 & 0.0884 \\
\hline & Ocaña-La Roda & 2004 & 127.5 & Interurban & Single road & Free highway & 0.0797 & 0.0925 \\
\hline \multirow[t]{7}{*}{ Group 2} & R-2 Madrid-Guadalajara & 2000 & 62.3 & Suburban access to Madrid & Free highway & Public transport & 0.0800 & 0.1900 \\
\hline & R-3 Madrid-Arganda & 1999 & 31.8 & Suburban access to Madrid & Free highway & Public transport & 0.0761 & 0.1002 \\
\hline & R-5 Madrid-Navalcarnero & 1999 & 28.9 & Suburban access to Madrid & Free highway & Public transport & 0.0602 & 0.1202 \\
\hline & R-4 Madrid-Ocaña & 2000 & 52.5 & Suburban access to Madrid & Free highway & Public transport & 0.0761 & 0.1002 \\
\hline & Eje aeropuerto & 2002 & 9.4 & Urban access to the airport & Free highway & Public transport & 1.5100 & 1.5100 \\
\hline & Madrid-Toledo & 2004 & 60.0 & Suburban access to Madrid & Free highway & Public transport & 0.0773 & 0.0926 \\
\hline & Circunvalación de Alicante & 2004 & 28.5 & Urban bypass & Free highway & & 0.0682 & 0.0869 \\
\hline \multirow[t]{3}{*}{ Group 3} & $\begin{array}{l}\text { Málaga-Estepona- } \\
\text { Guadiaro }\end{array}$ & $\begin{array}{l}1996 / \\
2000\end{array}$ & 75.7 & Interurban & Single road & & 0.1991 & 0.3249 \\
\hline & Alicante-Cartagena & 1998 & 76.6 & Interurban & Single road & Free highway & 0.0575 & 0.1021 \\
\hline & Cartagena-Vera & 2004 & 112.6 & Interurban & Single road & Free highway & 0.0315 & 0.0926 \\
\hline
\end{tabular}


public deficit of Spain just when, because of the economic crisis, the country is being required to cut its deficit.

\section{Main Features of Concession Contracts in Spain}

Toll highway concessions in Spain have retained most of their distinctive features throughout the years, even though there are some differences between the concessions awarded in the first period (1967-1975) and the concessions awarded in the third period (from 1996 to the present). Procurement of highway concessions in Spain has been done largely on the basis of an "open procedure." This procedure means that any company that fulfills the minimum requirements, as set out by the government in the contract's provisions, in the main having to do with that company's previous experience in operating highways and evidence of sufficient financial strength, is allowed to participate in the tendering process. Unlike other long-term infrastructure contracts in the world, e.g., design build finance operate contracts in the United Kingdom and most of the PPP contracts in Germany, concession contracts in Spain were not agreed upon in negotiations between the government and the bidders. Rather, the government submits standard contracts to the bidders through the bidding terms that eventually will have to be accepted by all the concessionaires.

The concession contracts in Spain are consequently rather incomplete since they are not negotiated for each project. However, transaction costs for both bidders and the government are very low in Spain as compared to other countries. This enables many companies to take part in the tender, which enhances competition and efficiency (Sánchez-Soliño and Gago 2010). This is probably the most important reason why the number of bidders participating in the tendering processes for highway concessions in Spain is often quite large (Vassallo and Sánchez-Soliño 2007).

Another feature of concession tenders in Spain is that, although the government requires the bidders to submit a business plan in their offers, the government does not require that they have to reach a financial close before the contract is awarded. In spite of that, once the contract is awarded, the bidding terms usually establish a deadline for the concessionaire to reach the financial close. For toll highways, maximum toll levels are set up in the contract for each one of the preestablished vehicle categories. According to the contract, the tolls are updated every year to bring them into line with inflation. The contracts permit the concessionaires a certain flexibility in reducing the tolls outside of the peak hours. In Table 1, the toll rates of the concessions analyzed in this paper are included.

Another innovation recently introduced in Spain is the so-called "progress clause." This clause consists of requiring the concessionaire to maintain and operate the public works according to the technical, environmental, and safety regulations that are currently in force and applicable. The aim of this clause is to guarantee that the concessionaire is going to adequately maintain and operate the highway throughout the years. Since the implementation of this clause in 2003, the technological risk has been transferred to the private sector.

The risk allocation principles followed by concession contracts in Spain establish that the private sector should be allocated most of the market risks. In spite of that, the legislation still permits allocation to the government of the risks that are either manageable by the government or cannot be sensibly managed by any other stakeholders (Vassallo and Gallego 2005). According to Spanish law, the government has the right to change the terms of the contract to bring it more closely into line with the public interest. If this change affects the economic balance of the concession, the initial conditions can be modified in favor of either the concessionaire or the government in order to compensate for this change. Similarly, if the government takes an action not foreseen when the contract was signed and this action substantially affects the economics of the contract, the economic balance should also be reestablished. Moreover, the Spanish legislation requires that the government must reestablish the economic balance of the contract to the benefit of the relevant party when circumstances of force majeure, understood by the Spanish legislation as fire caused by atmospheric electricity, natural phenomena with catastrophic implications, and damages caused by war and serious alterations of the public order, lead directly to substantial disruption of the financial terms of the concession. In addition to that, Spanish law enables but does not oblige the contracting parties to set up a procedure to mitigate traffic risk by setting up a minimum and maximum threshold in the terms for any variable related to the financial result, e.g., traffic and revenues, of the concession as defined in the bidding terms. Unfortunately, this measure has not been adopted yet in any of the toll concession highways in Spain.

\section{Effects of Recession in Toll Highway Concessions in Spain}

This paper focuses on the analysis of the toll highway concessions awarded in the third stage mentioned previously, from 1996 up to now. Therefore, the paper concentrates just on the short-term dislocation caused by the recession. The old concessions, i.e., those awarded in the early 1970s, are set aside for several reasons. First, most of the concessions awarded during that first stage are about to reach their end so the impact of the crisis is not so significant for the viability of the business. Second, there is little information about the offers that the bidders made when those concessions were granted so long ago, making it difficult to compare their estimates with the real outcomes.

\section{Traffic Share in Corridors}

Toll highways in Spain have always a rival route, the free alternative serving the same corridor, in such a way that the users of highways have the option to choose between the toll highway that offers them better quality and shorter travel time and that free alternative, often a conventional single road and in some cases a free highway, which offers them lower quality and longer travel times. Table 1 describes the characteristics of the competition in the main corridor and other alternative competition, such as public transportation around the urban areas or free highways which, not being located in the same corridor, may become attractive alternatives for some origin-destination pairs.

Table 2 shows the traffic share of the toll highways in their main corridors up to 2009 (data for 2010 were not available in early 2011). Toll highways competing with single roads have a much greater share than toll highways competing with free highways. The share of the urban concessions included in Group 2 diminished from 2008 to 2009 at a sharper pace than did the share of those concessions included in Groups 1 and 3, which mostly compete with single roads.

Table 2 compares the traffic growth in the toll highways with traffic growth in their corridors in three different periods: from the beginning of their operation to 2007; from 2007 to 2008 when the recession was beginning; and from 2008 to 2009 when the recession was at its peak. Several results emerge from this analysis. The first is that before the recession, from the beginning of the concession's operation up to 2007, most of the toll highway concessions experienced traffic growths higher than the average GDP growth in Spain and higher in general than the traffic growth in their respective corridors. This means that while the economy 


\begin{tabular}{|c|c|c|c|c|c|c|c|c|c|c|}
\hline & & \multirow{2}{*}{$\begin{array}{c}\text { First year } \\
\text { of } \\
\text { operation }\end{array}$} & \multicolumn{2}{|c|}{$\begin{array}{l}\text { Share in } \\
\text { the main } \\
\text { corridor }(\%)\end{array}$} & \multicolumn{3}{|c|}{ Traffic growth in the toll highways (\%) } & \multicolumn{3}{|c|}{ Traffic growth in the corridor $(\%)$} \\
\hline \multicolumn{2}{|c|}{ Toll highway } & & 2008 & 2009 & $\begin{array}{l}\text { First year of } \\
\text { operation; } 2007\end{array}$ & 2007-2008 & 2008-2009 & $\begin{array}{c}\text { First year of } \\
\text { operation; } 2007\end{array}$ & $2007-2008$ & 2008-2009 \\
\hline \multicolumn{2}{|c|}{$\begin{array}{l}\text { Average annual growth of the real } \\
\text { GDP in Spain }\end{array}$} & & 0.9 & -3.7 & & 0.90 & -3.70 & & 0.90 & -3.70 \\
\hline \multirow[t]{5}{*}{ Group 1} & Ávila-Villacastín & 2002 & 67.3 & 67.8 & 6.50 & -1.00 & 17.26 & -0.65 & -5.5 & 16.21 \\
\hline & $\begin{array}{l}\text { Santiago-Alto de Santo } \\
\text { Domingo }\end{array}$ & 2003 & 51.8 & 51.8 & 13.50 & 3.70 & 3.13 & 7.40 & -2.91 & 3.18 \\
\hline & Segovia-El Espinar & 2003 & 55.6 & 52.9 & 5.90 & -3.24 & 5.58 & 9.70 & -23.00 & 10.97 \\
\hline & León-Astorga & 2003 & 33.4 & 33.0 & 2.60 & 4.43 & -4.41 & 1.30 & 1.44 & -3.36 \\
\hline & Ocaña-La Roda & 2006 & 50.3 & 50.4 & 8.20 & 2.47 & -3.29 & -1.80 & -5.45 & -3.46 \\
\hline \multirow[t]{7}{*}{ Group 2} & R-2 Madrid-Guadalajara & 2003 & 11.2 & 10.3 & 8.80 & -3.66 & -11.8 & 2.90 & -3.72 & -4.00 \\
\hline & R-3 Madrid-Arganda & 2004 & 13.5 & 12.8 & 15.00 & -4.19 & -4.54 & 4.60 & 2.38 & 0.94 \\
\hline & R-5 Madrid-Navalcarnero & 2004 & 12.2 & 11.6 & 3.70 & -4.46 & -5.89 & 6.20 & -5.47 & -0.76 \\
\hline & R-4 Madrid-Ocaña & 2004 & 16.6 & 14.7 & 22.00 & -8.85 & -15.2 & 7.80 & -13.80 & -4.78 \\
\hline & Eje aeropuerto & 2005 & 53.8 & 52.3 & NA & 0.77 & -2.59 & NA & 11.40 & 0.22 \\
\hline & Madrid Toledo & 2006 & 4.1 & 3.44 & -0.10 & -13.2 & -21.6 & 6.90 & 9.19 & -5.63 \\
\hline & Circunvalación Alicante & 2007 & 10.6 & 9.1 & - & 7.16 & -21.3 & NA & -4.35 & -8.44 \\
\hline \multirow[t]{3}{*}{ Group 3} & Málaga-Estepona-Guadiaro & 1999 & 48.1 & 46.4 & 6.40 & -5.95 & -8.02 & 1.60 & -4.54 & -4.55 \\
\hline & Alicante-Cartagena & 2001 & 69.1 & 69.1 & 9.70 & -8.34 & -9.33 & 8.00 & -6.73 & -9.29 \\
\hline & Cartagena-Vera & 2007 & 50.5 & NA & - & 2.88 & -13.6 & - & -1.93 & NA \\
\hline
\end{tabular}

Note: NA $=$ not available.

was doing well, the users tend to be more prone to use the toll highways than their free alternatives. There are two reasons that might explain that. The first one is that the greater the income of families and firms, the higher will be their willingness to pay. The second reason is that the greater the total traffic in the corridor, i.e., traffic that increases when the economy does well, the worse will be the congestion problems in the free alternative.

The second result is that the effect of the crisis, which started in 2008 and reached its peak in 2009 , had a great impact on the traffic volumes in almost all the corridors. The effect of the crisis was even more notable in the toll highways, particularly at the peak of the economic recession. This fact demonstrates that toll highway concessions reflect and amplify the state of the economy. If the economy does well, traffic in toll concessions will do even better; if the economy performs poorly, traffic in toll concessions will perform even more poorly. A consequence of this analysis is that toll concessions competing with direct alternatives are actually more risky than the average risk for the economy.

The third result shows that the impact of the crisis is, overall, greater in toll highways included in Groups 2 and 3 than it is in toll highways located in Group 1. For the case of Group 2, urban toll highways, the explanation might be that these concessions have greater competition than the ones in other groups. For the case of Group 3, seasonal toll highways, the reason might be that seasonal traffic is expected to be more affected by the recession.

\section{Business Performance of Toll Highway Concessions}

This section describes the risks that have been affected the most by the economic recession: traffic demand and cost overruns in the acquisition of the right of way. The crisis had a great impact on the performance of the concession contracts, particularly on the main source of revenues for the concessionaires, which is traffic demand. The behavior of actual traffic compared to the expected traffic is a key component of the ultimate profitability of the concessionaire (Baeza 2008). Table 3 summarizes traffic deviations in the 15 highways analyzed. These deviations measure the difference between the actual traffic and the estimates originally made and relied on by the concessionaire in its bid. Negative values of the deviations show traffic overestimations, whereas positive values show traffic underestimation.

In Table 3, the following results are obtained. First, traffic levels were substantially overestimated by all the concessionaires during the years analyzed. The only exception was the Málaga-EsteponaGuadiaro highway where traffic predictions underestimated traffic from year 4 on. However, overestimates of demand do not occur only in Spain but they are quite usual in transportation infrastructure facilities, particularly in highway projects (Flyvbjerg 2005; Flyvbjerg et al. 2005).

Second, on average, the accuracy of the estimates tends to improve over time if the economy grows. This may be caused by what is called the "ram up" effect (Bain 2009). This effect means that during the first few years after a new highway is opened, the new highway has fewer users than it would have had if the users were used to the existence of the highway. This happens because the users need a certain lapse of time to familiarize themselves with the existence of the new infrastructure and its effect within the transportation network.

However, the trend described previously changed in 2008 because of the recession. For this year, the traffic estimates turn out to be less accurate than for the previous year. The only exceptions to this rule are the highways that in 2008 were in their first years of the ramp-up period (Cartagena-Vera and Circunvalación de Alicante). In 2009, the outcome became even less favorable for the concessionaires.

Third, the toll motorways that compete directly with a free highway, which coincide with the Group 2 highways (the rows printed in bold and italics in Table 3) show, in general, higher levels of overestimation than is the case with the toll highways that mainly compete with single roads. The overall consequence of the traffic behavior is that greenfield toll concessions tend to improve their performance over the years if the economy grows positively. However, most of the toll concessions awarded in Spain from 1996 on had to tackle the economic recession just at the ramp-up period, which is the very period when the greatest traffic growths were expected. 


\begin{tabular}{|c|c|c|c|c|c|c|c|c|c|c|c|c|}
\hline \multirow[b]{2}{*}{ Toll motorway concession } & \multirow{2}{*}{$\begin{array}{l}\text { First year } \\
\text { of operation }\end{array}$} & \multicolumn{11}{|c|}{ Traffic deviations [(real traffic-forecasted traffic)/forecasted traffic] $(\%)$} \\
\hline & & 1999 & 2000 & 2001 & 2002 & 2003 & 2004 & 2005 & 2006 & 2007 & 2008 & 2009 \\
\hline Average annual growth of the real GDP in Spain & & 4.7 & 5 & 3.6 & 2.7 & 3.1 & 3.3 & 3.6 & 4 & 3.6 & 0.9 & -3.7 \\
\hline Málaga-Estepona-Guadiaro & 1999 & -45 & -28 & -18 & 4 & 18 & 22 & 25 & 28 & 29 & 1 & NA \\
\hline Alicante-Cartagena & 2001 & & & -24 & -21 & -10 & -4 & -4 & -5 & -7 & -21 & NA \\
\hline Ávila-Villacastín & 2002 & & & & -34 & -25 & -19 & -20 & -19 & -14 & -15 & NA \\
\hline Santiago-Alto de Santo Domingo & 2003 & & & & & -43 & -33 & -34 & -32 & -26 & -26 & -26 \\
\hline Segovia-El Espinar & 2003 & & & & & -28 & -31 & -30 & -25 & -19 & -25 & NA \\
\hline León-Astorga & 2003 & & & & & -28 & -44 & -46 & -45 & -37 & -37 & -41 \\
\hline R-2 Madrid-Guadalajara & 2003 & & & & & -63 & -58 & -58 & -47 & -43 & -48 & -54 \\
\hline R-3 Madrid-Arganda & 2004 & & & & & & -57 & -47 & -41 & -44 & -51 & -59 \\
\hline R-5 Madrid-Navalcarnero & 2004 & & & & & & -58 & -55 & -47 & -43 & -50 & -50 \\
\hline$R-4$ Madrid-Ocaña & 2004 & & & & & & -56 & -57 & -45 & -36 & -45 & -56 \\
\hline Eje aeropuerto & 2005 & & & & & & & -79 & -65 & -61 & -65 & -71 \\
\hline Ocaña-La Roda & 2006 & & & & & & & & -49 & -55 & -56 & NA \\
\hline Madrid-Toledo & 2006 & & & & & & & & -82 & -74 & -83 & $N A$ \\
\hline Cartagena-Vera & 2007 & & & & & & & & & -70 & -65 & NA \\
\hline Circunvalación de Alicante & 2007 & & & & & & & & & -40 & -37 & -55 \\
\hline
\end{tabular}

Note: NA = not available.

The traffic issue was aggravated in some concessions belonging to Group 2 due to the high cost overruns in the acquisition of the right of way. In Spain, the expropriation risk has often been transferred to the private sector. The process works in such a way that once the government declares that the acquisition of the right of way is in the "public interest," the concessionaire will be in charge of managing the land acquisition process under the government umbrella. To expropriate land, the concessionaire has to pay the land's owner the value originally set by the government. If the landowner does not agree with that value, he can appeal to the court of justice. If the court of justice concludes that the value of the land is higher than the amount fixed the government, the concessionaire will have to pay that higher amount to the landowners.

In the case of some of the toll highways giving access to Madrid City (R-2, R-3, R-4, and R-5), the government thought that the value of the land necessary to build them was going to be similar to the cost for rural properties since the land acquired had qualified as rural land. However, the landowners appealed to the court of justice and that court eventually resolved matters in favor of the landowners, concluding that the land acquired was located close to the city and the construction of a new highway raised the value of the land nearby to a greater extent than previously assumed. As a consequence, the court stated that the concessionaire had to pay a much higher amount to the landowners, approximately 10 times the original value that had been set by the government (Ortega et al. 2011).

\section{Measures Adopted to Deal with the Recession}

Concession contracts for toll highway concessions in Spain have fully transferred traffic risk to the concessionaires. As mentioned above previously, the Spanish legislation enables the government to change the economic balance of the contract in very few circumstances: force majeure, changes in the contract terms imposed by the government, and circumstances prompted by the government that may substantially affect the economics of the concession contract. In its latest version, the law also permits the incorporation of traffic risk mitigation mechanisms in the contracts. The Spanish government has, however, never used them for toll highway concessions.
The poor economic performance of some concessions, especially the suburban toll highway concessions around Madrid, pushed the government to adopt measures to help the concessionaires to improve the viability of their businesses. In these concessions, traffic overestimation turned out to be particularly high and cost overruns caused by higher values for land that had to be expropriated became difficult for the concessionaires to bear. The government will also be substantially harmed if the concessions ultimately go bankrupt and the contracts have to be terminated. As noted previously, if a concession goes bankrupt, according to the Spanish concession law, the government has to compensate the concessionaire for those works already built and not yet amortized. This will result in a high cost for the government just when the economy is not doing so well and the government has scarce budgetary resources and has submitted to a strict control of its public deficit. For all the reasons explained previously, the government approved a set of measures in order to mitigate the effects of the recession and the large cost overruns in the acquisition of the right of way experienced by some concessionaires. The most important measure adopted by the government was the award of subordinated public participation loans (SPPLs) to the concessionaires in order to help them to pay the cost overruns for acquiring the right of way.

Subordinated public participation loans have the following characteristics (Vassallo and Sánchez-Soliño 2007):

- The SPPLs always have to be subordinated to senior debt. Consequently, participating loan holders, i.e., the government in the case of SPPLs, will be paid back only after the concessionaire has met its obligations to the senior lenders. However, the participating loan holders will be paid back before the shareholders receive any dividend.

- The expected rate of return of SPPLs is related to the performance of the concession. In other words, the better the outcome of the concession in terms of traffic, sales, profits, or whatever other variable had been specified in the contract, the greater the rate of return of SPPLs. The idea behind this approach is that the government partially shares the profits and losses of the project with the concessionaire.

- The expected yield of SPPLs should be market based since otherwise the government could make use of SPPLs to provide hidden subsidies. 
The SPPLs have a definite effect on the traffic risk-sharing approach of the concession since the higher the real traffic in relation to that previously forecasted, the higher will be the interest rate to be paid by the concessionaire to the government. This way, additional unpredicted profits will be shared between the concessionaire and the government. If ultimately the real traffic is much higher than expected, the government will receive higher interest rates while the concessionaire will have lower profits. Consequently, the government's incentive coincides with the concessionaire's incentive since the better the project performs, the larger the SPPL interest will be. This is the reason why SPPLs are regarded as a creative means of promoting PPP projects for highway concessions.

The SPPLs have important advantages as well in terms of national accounting. Unlike subsidies, SPPLs are treated for accounting purposes as a financial investment according to the European National Accounting Standards defined by EUROSTAT (2002). As long as those financial investments are made based on market conditions, SPPLs will have no influence on the national public deficit. This norm has the problem that, because there is no competition, it is difficult to know if the loan was provided on market-based conditions. This means that the government could misuse this mechanism as an implicit subsidy by providing loans that the concessionaire in the end will not be able to pay back. The fact that SPPLs have no influence on the national public deficit is very important for European countries. The establishment of a common currency in the European Union forced the member states aiming at joining the euro zone to fulfill strict macroeconomic criteria to encourage convergence among the EU members. Among those criteria, the lowering of the public deficit became both the most important and, at the same time, the most difficult one to meet.

The SPPLs awarded to the concessionaires set interest rates that would vary depending on the future level of traffic. Thus, if in the end the traffic becomes much higher than expected, the concessionaire will have to pay a larger interest rate to the SPPL holder. However, if traffic remains much lower than expected, the interest rate to be paid will be $1.75 \%$, which is almost equal to the current level of inflation.

However, the economics of the concessions was so poor that the sole award of SPPLs to the concessionaires was not enough to make the expected yield of the SPPLs to be market based. In order to solve this problem, the government changed the contract terms of four of the concessions. The Radial 2 concession, a suburban toll highway to alleviate congestion in getting in and out Madrid City, was extended by 14 years, and the tolls were allowed to be increased above the levels originally established in the contract. The amount of the toll rise has not yet been made public.

The concession contact including both Radial 3 and Radial 5, also suburban toll highways in the metropolitan area of Madrid, was authorized to raise their tolls over the values fixed in the original contract terms. The aim of this change in the original contract terms was to guarantee that the project will be able to pay back the SPPLs provided by the government. This measure has been implemented also in the Alicante Cartagena concession. The contract terms of the concession Málaga-Alto de Las Pedrizas, which is still under construction, has also been changed by the government through a 17-month extension of the concession duration originally established in the contract and the rise of the tolls originally set up in the contracts. The amount of the toll rise has not yet been made public.

In addition to the measures described previously, in December 2010, the Parliament of Spain had just approved a law to support the concessionaires who have suffered the traffic shortfalls caused by the economic recession. To that end, the law enables the government to guarantee to the concessionaires up to $80 \%$ of the revenues originally forecasted for a period of 3 years (2011, 2012, and 2013). Consequently the government will have to pay the difference between $80 \%$ of the forecasted revenues and the revenues actually collected by each concessionaire. As is shown in Table 3, the revenues for most of the toll concessions are around 50 and $70 \%$ of their estimates. The funds to be provided by the government will be obtained through SPPLs. Consequently, they will have to be paid back to the government with an interest rate structure similar to the one described previously. In 2011, the government will disburse up to 80.1 million Euro to support the concessions that are enduring serious traffic problems: Radial 2, Radial 3 and 5, Radial 4, the new access to Madrid Barajas Airport, Madrid-Toledo, Cartagena-Vera, Ocaña-La Roda, and Circunvalación de Alicante (Baeza and Vassallo 2011). These are the concessions whose operation started in 2003 and after, and consequently they have been intensely affected by the economic recession. Although the law does not mention this explicitly, this measure will likely imply changes in the original contract terms to facilitate the payback of the SPPLs.

\section{Conclusions and Recommendations}

The preceding analysis shows the large impact that an economic recession can have on the outcome of concession contracts, particularly if the risks have not been correctly allocated. The conclusions of this research are the following:

- Traffic demand in toll road highway concessions competing with free alternatives is extremely sensitive to the economic cycles. This means that when the GDP grows positively, traffic in toll highway concessions tends to grow even more positively. This is true when the economy is suffering. When GDP decreases, traffic in toll highway concessions tends to decrease even more sharply than does the GDP.

- The sensitivity referred to previously becomes greater in the cases of seasonal toll highways and in urban toll highways competing with free congested highways than in toll highways with more stable traffic demands. These two first conclusions are easily verifiable in Tables 1 and 2 .

- The results from the Spanish case shown in Table 3 suggest that allocating the bulk of traffic risk to the concessionaire, particularly in those concessions whose traffic demand is specially sensitive to GDP (urban and seasonal concessions), may be too risky to be successfully managed by the private sector. The implementation of either traffic risk mitigation mechanisms or payment approaches based on availability may offer a good way to solve this problem.

- The case of Spain demonstrates that the government often prefers to renegotiate rather than terminate the concession contract earlier. This happens because the guarantee provided by the Spanish Law in case of bankruptcy may end up being very costly for the government.

- The guarantee referred to previously does not make much sense from the standpoint of incentives to the bidders in the tender. If the bidders understand that the government does not have any incentive to allow the concession to go bankrupt, they will more likely make very aggressive offers to win the contract at all costs with the expectation of renegotiating in the future. Consequently, the procurement mechanism itself would be undermined.

- The case of Spain shows how the renegotiation of concession contracts may result in negative consequences for the users who, 
in the end, have to pay more through the rise in the toll rate or in the extension of the concession term. In order to avoid this kind of renegotiation, the government must devote whatever time is necessary to arrive at accurate estimates and to draft contracts of the highest quality that cover all eventualities.

\section{References}

Baeza, M. A. (2008). "Planificación económico financiera de las concesiones de autopistas de peaje. Un estudio empírico del caso español." Ph.D. thesis, Universidad de Granada, Granada, Spain (in Spanish).

Baeza, M. A., and Vassallo, J. M. (2011). "La intervención de la administración ante las dificultades financieras de las sociedades concesionarias de autopistas de peaje." Presupuesto y gasto público, 65, 51-60 (in Spanish).

Bain, R. (2009). "Error and optimism bias in toll road traffic forecasts." Transp., 36(5), 469-482.

Banco de España. (2011). Boletín económico Marzo 2011, Madrid, Spain.

European Monetary Institute. (1996). "Progress towards convergence.” 〈http:// www.ecb.europa.eu/pub/pdf/conrep/cr1996en.pdf (Mar. 25, 2011).

EUROSTAT. (2002). "ESA95 manual on government deficit and debt". European Commission, Luxembourg.

Flyvberg, B. (2005). "Measuring inaccuracy in travel demand forecasting: Methodological considerations regarding ramp up and sampling." Transp. Res. A: Policy Pract., 39(6), 522-530.
Flyvberg, B., Skamris Holm, M., and Buhl, S. (2005). "How (in)accurate are demand forecasts in public works projects? The case of transportation." J. Am. Plann. Assoc., 71(2), 131-146.

Instituto Nacional de Estadística (INE). (2009). "Desarrollo sostenible 2008." Principales indicadores de España para el seguimiento de la Estrategia de DS de la UE, Madrid, Spain (in Spanish).

Izquierdo, R., and Vassallo, J. M. (2004). "Nuevos sistemas de gestión y financiación de infraestructuras de transporte." Colegio de Ingenieros de Caminos, Canales y Puertos, Madrid, Spain (in Spanish).

Organisation for Economic Co-operation and Development (OECD). (2007). Principles for private sector participation in infrastructure, Paris.

Ortega, A., Baeza, M. A., and Vassallo, J. M. (2011). "Autopistas de peaje en los accesos a Madrid: ¿Qué lecciones debemos aprender para el futuro?" Revista de obras públicas, 3519, 41-50, (in Spanish).

Sánchez-Soliño, A., and Gago, P. (2010). "Transaction costs in publicprivate partnerships: Comparing procurement procedures." Transp. Rev., 30, 389-406.

Vassallo, J. M. (2011). "Política de infraestructuras del transporte en la unión Europea.” Noticias de la Unión Europea, in press (in Spanish).

Vassallo, J. M, and Gallego, J. (2005). "Risk-sharing in the new public works concession law in Spain." Transportation Research Record 1932, Transportation Research Board, Washington, DC, 1-8.

Vassallo, J. M, and Sánchez-Soliño, A. (2007). "Subordinated public participation loans for financing toll highway concessions in Spain." Transportation Research Record 1996, Transportation Research Board, Washington, DC, 1-8. 